\title{
On the Perpetuation and Contestation of Racial Stigma: Urban Roma in a Disadvantaged Neighbourhood of Szeged
}

\author{
Remus Crețan ${ }^{\mathrm{A}}$, György Málovics ${ }^{\mathrm{B}}$, Boglárka Méreiné Berki ${ }^{\mathrm{B}}$ \\ Received: September 01, 2020 | Revised: November 02, 2020 | Accepted: November 04, 2020 \\ doi:10.5937/gp24-28226
}

\begin{abstract}
Stigmatisation of Roma people has long received attention in the academic literature but the internalisation of stigma among segregated urban Roma has been little researched. By adopting a theoretical perspective on collective identity and (urban Roma) racial stigmatisation, this paper aims to 1) understand the broader nature of urban Roma stigmatisation maintained by the non-Roma people and among the Roma, and 2) better position the internalisation of stigma and the burden of Roma stigmatisation. The paper uses Participatory Action Research (PAR) as a research methodology, taking a disadvantaged neighbourhood of the city of Szeged, Hungary as a case study. The findings suggest that stigmatisation against urban Roma is a process which has deeply rooted historical backgrounds, and current efforts which strive for desegregation and integration of urban Roma will be difficult to implement, as stigmatisation remains in the collective mentality. The importance of this study rests on bringing all major dimensions of stigma together, highlighting what policymakers should consider when addressing them in the longer term. We argue that the existing urban policies towards the Roma people need to be readdressed, with clear power given to the voices of the Roma, particularly from institutions which aim to protect them.
\end{abstract}

Keywords: urban Roma; racial stigma; internalisation of stigma; segregation; disadvantaged neighbourhood; Szeged; Hungary

\section{Introduction}

The burden of stigmatisation has been a challenge for the Roma people in Europe for centuries (Powell \& Lever, 2017). From the slavery period to the current neoliberal pressures and nationalist extremism extending to all levels of European society, Roma people have often been placed at the bottom of modern societies, leading to actions of Romaphobia (McGarry, 2017; van Baar, 2011). Images of Roma beggars paired with the media portrayal of Roma as thieves and drug addicts, linking them to prostitution activ- ities, have been increasingly prevalent both in the political and mass-media space (Crețan \& O'Brien, 2019). Attitudes of vilification of Roma people are not usually seriously considered by political actors and policymakers, indirectly maintaining a form of "invisibilisation" of anti-Roma racism (Powell \& van Baar, 2019), and highlighting a need for a more critical perspective on 'whiteness' and the ongoing injustices against Roma communities (McElroy, 2020; Shmidt \& Jaworsky, 2020).

\footnotetext{
A Department of Geography, West University of Timisoara, Vasile Parvan no 4300233 Timișoara, Romania; remus.cretan@e-uvt.ro

B Faculty of Economics and Business Administration, University of Szeged, H-6722, Kálváris sgt. 1., Szeged, Hungary; malovics.gyorgy@eco.u-szeged.hu; mereine@gmail.com

* Corresponding author: György Málovics; email: malovics.gyorgy@eco.u-szeged.hu
} 
By being less focused on relevant relations, interactions and experiences of the Roma people (Grill, 2018), the existing literature on Roma tends to focus more on disadvantages visible in relations with the state institutions, as well as the impact of punitive policies. State discrimination and the mechanisms of governing Roma migration (Humphris, 2019; Picker, 2017; Toma \& Fosztó, 2018; van Baar et al., 2019; Vrăbiescu, 2017), as well as its ghettoised and racialised education and socioeconomic position (Berescu, 2011, 2019; Clough Marinaro, 2017; Filčák \& Steger, 2014; Ivasiuc, 2020; McElroy, 2020; O’Nions, 2010; Picker, 2017; Vincze \& Rat, 2013; Vincze, 2019; Voiculescu, 2019) are issues that have been extensively debated, yet little is known about the everyday manifestations of contemporary stigmatisation of the Roma (see Crețan et al., 2021; Pulay, 2018).

Hungary is one of the European countries where Roma communities have always been stigmatised, with structural racism accounting for the post-socialist period at a higher level. Elements of stigmatisation, discrimination and marginalisation accompanied by a narrative of vilification allow for Roma communities to be blamed for the majority of the weaknesses in Hungarian society (Málovics et al., 2019a).

The present paper aims to a) understand the broader nature of urban Roma stigmatisation maintained by the non-Roma people and among the Roma, and b) better position the internalisation of stigma and the burden of Roma stigmatisation through the voices of the Roma in one of Hungary's biggest cities, Szeged.

The present paper begins by presenting the literature review on collective identity, disadvantaged urban communities and the burden of urban stigmatisation. The second part of the paper draws on positioning the segregated areas in Szeged. The following section highlight methodology and data used in the study. Lastly, the results and a thorough discussion of the findings and conclusions of the research are presented.

\section{Collective identity, disadvantaged urban communities, and the burden of racial stigmatisation}

Collective identities aid in the establishment of important directions around whether groups are accepted or rejected. Shared meanings and cultural representations are negotiated and (re)produced through individuals interacting with each other (Hunt \& Benford, 2004). Adherence to certain norms allows members to rely on some general guidelines of their shared identity. Such cohesion could bring into discussion the presence of the 'other', especially in a context in which collective identities might reinforce patterns of exclusion.
Stigmatisation is an important tool through which collective identities can be preserved, supporting 'the logic' of maintaining distance from 'the others'. Goffman's (1963) concept of stigma has proved valuable in the development of public understandings of stigmatisation. Power relations can recount to economic, social, or political background and recent research on stigma has been focused on 'where stigma is produced, for what purposes, and by whom' (Tyler \& Slater, 2018).

Territorial stigmatisation is associated to certain urban areas of excluded groups, ultimately strengthening these power relations (see Wacquant, 2008; Wacquant et al., 2014). The place-based nature of urban stigma is a useful concept in understanding the occurrence of disreputable places and the practices through which power relations are produced. Furthermore, a clear understanding of the 'territorial' in territorial stigma is important to define (Sisson, 2020, because the neoliberal restructuring of capital resulted in different forms of resistance to territorial stigmatisation. Within this context, by focusing on gentrification in Parkdale, Toronto, Mervyn Horgan (2018) argues that legal, material and discursive practices are important when discussing territorial stigma, with issues of destigmatisation delineated on two levels: one that works to symbolically reinscribe stigmatised persons and housing forms, and another which operates in relation to gentrification-led displacement.

Place-based stigma reproduces negative stereotypes, constructing an internal moral order, creating a vicious link between place, class, and race. In this context, the discrepancy between the production of stigma by the external world and residents who internalise stigmatisation is less clear (Tyler \& Slater, 2018). Furthermore, there is a blurred line between internalisation of stigma and territorial stigma per se (Pinkster et al., 2020), with stigmatised residents holding a strong desire to create distance between place and space (Wacquant et al., 2014). In a study on spatial denigration in social media, Butler et al. (2018) emphasise that sometimes local residents reinforce stigmatising labels, creating unequal power relations which impact stigmatised people both from the outside and within the neighbourhood, irrespective of housing or human/individual stigma.

Racial stigmatisation against the Roma is a long historical process and urban racial issues have been abundantly accounted for in contemporary literature (Picker, 2017). Ethnic and/or racial segregation have a strong impact on the groups and individuals involved, strongly influencing their welfare. The nature of the impact caused by segregation strongly depends on the degree of involvement of different cultural influences at collective identity levels (Kaplan \& Douzet, 2011). The segregation phenomenon occurs when specific groups be- 
longing to one cultural identity exist in the space of different cultural origins. These groups may be either within or outside the social context but are frequently perceived as different in the majority society.

Roma stigmatisation in Central and Eastern Europe has benefited from ample research. Studies in the field have emerged from theoretical understandings of 'Romaphobia' in an attempt to underline stereotypes in the construction of Roma identity (McGarry, 2017; van Baar, 2011). Many of such studies have focused on the socioeconomic deprivation of urban and rural Roma communities, addressing issues including but not limited to territorial segregation, lack of education and labour market exclusion (Clough Marinaro, 2017; Foszto, 2018; Maestri, 2014; O’Nions, 2010; Picker, 2017; Powell, 2008; Voiculescu, 2019). The effect of corrective policies on the neglect of everyday experiences and interactions is also present in contemporary debates (Grill, 2018; Pulay, 2015), leading to increasing discussions of securitisation issues around the Roma people in Europe (van Baar et al., 2019). Moreover, the threat of racism in the current neoliberal times is obvious (Goldberg, 2019), with more racial trends against the Roma people on all levels, including housing and socioeconomic practices (Ivasiuc, 2020; Teodorescu, 2019; Vincze, 2019).

Eviction and stigmatisation of Roma communities in Central and Eastern Europe are two key factors that have been prevalent both in the urban space and in broader national contexts (Crețan \& O'Brien 2019; Crețan \& Light, 2020; Lancione, 2017; Málovics et al. 2019a; Málovics et al., 2019b; McElroy, 2020; Méreiné
Berki et al., 2017; Méreiné Berki et al., 2021; Zamfirescu \& Chelcea, 2020), highlighting an inherent need for more radical housing policies (Lancione, 2019). However, despite the acknowledgement of such needs, insufficient efforts have been made to understand the everyday manifestations of contemporary stigmatisation of the Roma, what the layered dimensions of racial stigmatisation of the marginalised urban Roma communities are, and how these are internalised by the local Roma people. In the context of urban marginalisation, there is an important gap in the existing literature, with approaches focused on identifying bottom-up initiatives directly from the experiences of Roma people lacking, and little understanding of how critical engagement in eradicating those dimensions of stigma can be established for solid empowerment policies for the Roma people to be implemented.

\section{Placing segregated Roma in Szeged}

Szeged is the fourth largest city of Hungary, located approximately 15 kilometres from the Serbian border and 30 kilometres from the Romanian border. The city is the administrative, cultural, and economic centre of the South-Great Plain region of Hungary, currently populated by approximately 167000 people.

The $20^{\text {th }}$ century was marked by the emergence of new industries, including textile, cable, rubber, and cosmetics businesses that were established in the city alongside the already present traditional industrial fields (paprika and hemp processing, tinned food, and salami production). However, most of these dissolved after the Hungarian regime change of 1989. Present-

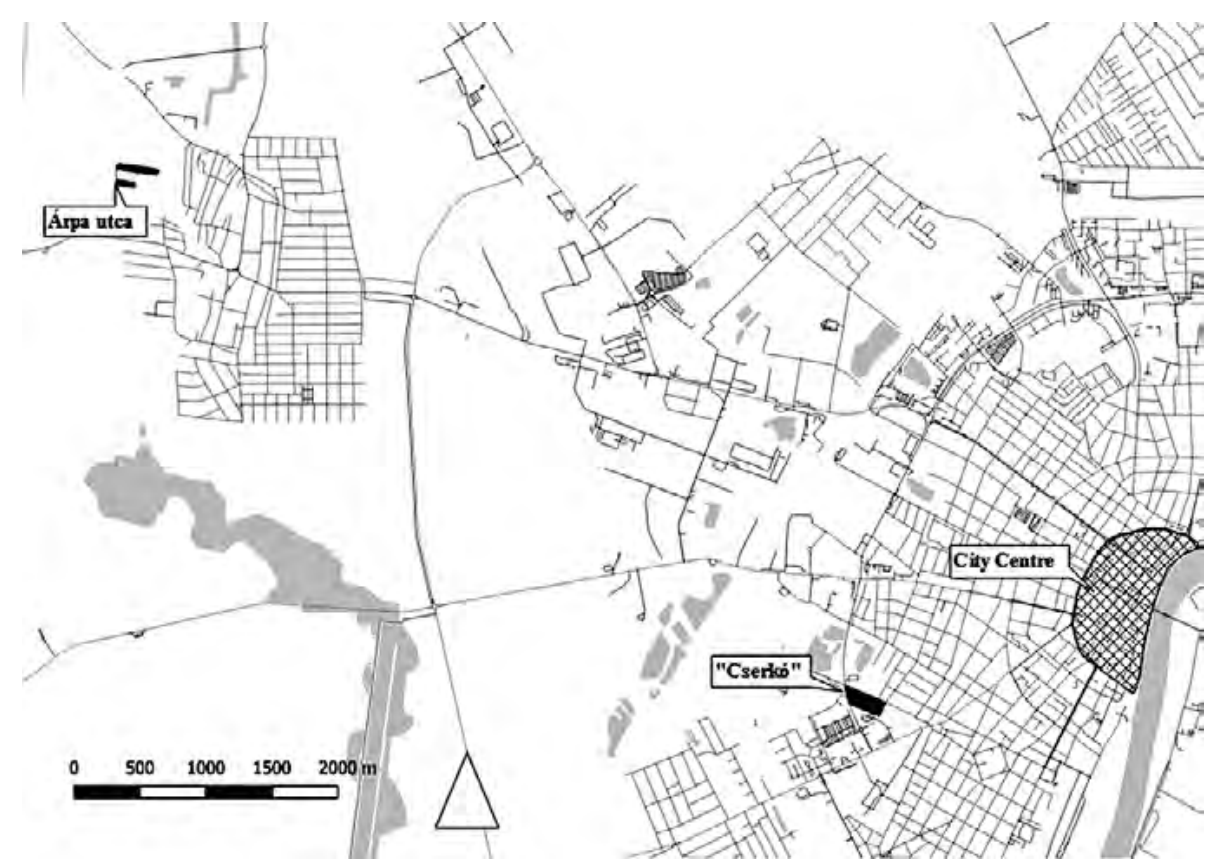

Figure 1. Segregated Roma neighbourhoods within the city of Szeged, Hungary Source: own illustration - shape file was created from OpenStreetMap data and it is licensed under the Open Database 1.0 License from: http://www.geofabrik.de/data/shapefiles.html 
ly, Szeged has no dominant private economic sector, and the economy of the city is strongly reliant on the University of Szeged as the largest employer of the city (Bajmócy et al., 2017).

Since their arrival in the city towards the end of the $19^{\text {th }}$ century, Roma communities have primarily lived in segregation, marginalised from the rest of the society. The "Cserepes sor segregated area" ("or "Cserkó", as called by its inhabitants) emerged during the 1970s, when the elimination and resettlement of the so-called "nagy putri" began (Málovics et al., 2019a). Ever since, Szeged maintains two segregated Roma areas, where approximately 400 Roma people lived until 2017. The smaller space of Kiskundorozsma, Árpa utca, includes houses in which about 125 inhabitants live in 4 buildings (16 flats). It is situated on the outskirts of the city. The second and larger area of Cserepes sor (see Figure 1), where interviews were carried out, is located at walking distance from the city centre and used to host approximately 250 inhabitants until 2017 when its removal begun (see Méreiné Berki et al., 2021). Segregated Roma neighbourhoods are primarily characterised by extreme poverty, inadequate and uncertain housing conditions, low level of education and an obvious lack of legal and stable employment opportunities.

In the context of spatial segregation of Roma communities, two main issues have impacted the life in the Cserepes sor segregated area to an essential extent until 2017, details of which are present in the empirical part of this paper. Firstly, community members have primarily had a diverse housing status, with some owning land and properties whilst others rented living spaces from the city council. The more unfortunate ones lost the legal occupancy rights due to overdue or unpaid rent, becoming illegal squatters. Such instances have increased the difficulty of accurately estimating the real number of segregated occupants, with the latest official census data in 2011 reporting a total of 217 occupants, a number that does not account for illegal squatters and individuals who have lost their legal rights to permanent housing (see Méreiné Berki et al., 2021).

The underestimation of the real number of occupants, paired with the desegregation process that started during the present research was conducted has contributed to the emergence of significant conflicts within the community. Such conflicts have been amplified by the hope that the desegregation process will offer occupants certain benefits, under the presumption that (1) tenants will receive new, higher standard social housing for a slightly increased rent; and (2) owners will either receive the value of the property or an alternative flat/house in exchange whilst (3) illegal squatters and families without legal status will be displaced without any compensation. Under such presumptions, some owners and tenants have shown a slight tendency to- wards supporting the desegregation process, viewing it as an opportunity for a better life, whilst illegal squatters and families without legal status have opposed it, since the proposed process of desegregation plunges them into precarity and potential homelessness.

Secondly, the extended use of Novel psychoactive substances (NPS) by community members - a general problem in Hungary amongst marginalised youth (Kaló et al., 2017) - has also weakened inter-community ties and consequently led to increased inner-community conflicts. The presence of these drugs is often associated with the moving in of residents of a former segregated neighbourhood called "Airport", an area in close proximity to the local airport which was eliminated in 2005 by the local city council of Szeged.

The city council hired an association to persuade 17 families with approximately 70 people living in 11 flats of 28-30 square meters, in a building which also served as the local homeless shelter, to accept housing outside of Szeged. This proposal offered housing on farmsteads in smaller villages, 60-70 kilometres from Szeged, and some additional cash in exchange for flats at the Reptér segregated neighbourhood. Following intense persuasion, families accepted the deal however, most families could not integrate into the new environment. People continuously returned to Szeged certain families after a few weeks while others after years - and occupied flats which were by then out of use in the Cserepes sor area, becoming illegal squatters. The inter-community divide emerged as an "old resident" versus a "newcomer" attitude, creating tension towards former Reptér residents.

The number of Roma living in Szeged is likely to be around 4500-5000 according to self-declared members of the local Roma community, with approximately $10 \%$ of them living in the two mentioned segregated areas. The social situation of Roma in Szeged highlights a diversified circumstance: many Roma live close to the city centre, as tenants in old houses owned by the city, often concentrated in "mini-segregated spaces" (smaller flats owned by the city council, often lacking basic levels of sanitation and comfort). Additionally, a significant proportion of the Roma population lives in the areas scattered with concrete blocks of flats, most of which are also tenants in properties owned by the city.

During the socialist period, full employment was amongst the major political, economic, and ideological goals of the state (see Kornai, 1980). In consequence, state-owned companies provided employment for everyone and being unemployed counted as a crime. Roma in Szeged mostly worked in traditional and new industries settled by the socialist regime during this time, employed primarily as unskilled labour. In the context of education of the Roma community 
during the socialist regime, segregated schools in Szeged provided the community with education of rather low quality. Consequently, most adult Roma have only benefitted from primary education whilst many are illiterate. Despite the socialist system providing (forced) employment for the Roma, it did not enhance their level of education. However, school segregation is no longer present in Szeged, with the last segregated school of the city being closed down in 2007.

Following the regime change in 1989-1990 which brought about a swift decrease in the demand for unskilled labour, members of the Roma community could not integrate in the new job market as a consequence of low levels of education and continuous stigmatisation, becoming the first ones to lose their jobs. As a result, many members of the Roma community were forced to rely on social aid on from informal or illegal economic activities and work. Due to these historical processes of exclusion and stigmatisation, the majority of the Roma population still live in relative (or sometimes extreme) poverty in the city (Málovics et al., 2019a).

Based on property relations, the community can be divided by the extent to which "those who have property or legally rent here would literally kill illegal squatters", as stated by one of our interviewees. Those legally living in apartments are eager to leave the disadvantaged neighbourhood by selling their flats to the municipality due to certain behaviours (e.g. criminal activities) and the local atmosphere attributed to illegal squatters. Conversely, families without legal status and illegal squatters now face complete uncertainty and desperation, being ignored in all official planning documents and political decisions.

As a consequence of the desegregation process and despite owners' and tenants' contentment, considerable stress, challenges, and dangers are entailed for illegal squatter families. Although the interests of owner and tenant groups are acknowledged by the city council, illegal squatters remain the most marginalised within the segregated Roma community. Most illegal squatter families face enormous socio-economic problems including, but not limited to learned hopelessness, disabilities, alcohol and addiction, and their pure existence is denied by the municipality. As we presented above, most illegal squatter families are from the former 'Reptér' disadvantaged neighbourhood.

\section{Method and data}

The present research is based on semi-structured interviews that were carried out within a Participatory action research (PAR) process, with the involvement of local Roma and scholar activists starting in 2011 (see Málovics et al., 2018).

One of the authors of the present study has worked with segregated communities since 2015. Besides keeping a reflexive research diary during the whole period, she carried out qualitative data collection (fifteen semi-structured interviews) both in 2016, before the desegregation process had begun, and after the start of the desegregation process in 2018. The results of the present study are based on the interviews carried out in 2018. Interviews are part of the empirical research of the given author - providing a wider interview scope related to life and social capital in segregated urban Roma neighbourhood, as well as attitudes towards, and impacts of desegregation on the social capital and life of (de)segregated inhabitants. A total of 15 semi-structured interviews were conducted with 23 participants (see Table 1).

The reason for conducting both individual face-toface and small group interviews stems from the fact that people in segregated areas tend to move freely between each other's homes (Málovics et al., 2019b) - in the context of the present research, friends and relatives, also living in the segregated neighbourhood, simply entered the room and joined the interview process.
During the analysis of the results, it was observed that stigmatisation - even though not directly addressed by interview questions - is a substantial factor for interviewees, and has an enormous impact on their life. Different forms of stigmatisation, varying from personal/group (e.g. the Roma) stigmatisation to territorial and institutional stigmatisation, as well as patterns of internalisation of stigma, frequently appeared during the interviews.

Given the demographic diversity of the sampled community, the present research aimed to target a balanced sample, accounting for various characteristics - including age, gender and housing status (see Table 1). Approximately half of the interviewees had already moved out of the segregated area at the time of interviewing, whilst the other half still lived there.

With the consent of the participants, interviews were tape recorded and later typewritten, including the field notes of the context of each interview. Due to ethical constraints, the real names of the participants cannot be revealed. Instead, interviewees were coded in this article by using nicknames including age and gender.

Beside its ability to provide a bottom-up community perspective, PAR is an appropriate approach for the present research for many reasons. First, combining actions with observations and the explicit commitment of PAR towards equal and democratic academ- 
Table 1. Housing status and demographic characteristics of the interviewees

\begin{tabular}{|l|l|l|l|}
\hline № & Gender and age & Housing status & $\begin{array}{l}\text { Still lived in/moved out of the segregated } \\
\text { neighbourhood at the time of the interview }\end{array}$ \\
\hline 1 & male 57, female 56 & renter & moved \\
\hline 3 & male 40, female 29 & owner & moved \\
\hline 4 & male 60 8 & owner & moved \\
\hline 5 & male 68, male 32 & squatter & moved \\
\hline 6 & female 31 & Renter & moved \\
\hline 7 & male 61 & Renter & moved \\
\hline 8 & female - died at the age of 50, male 55 & squatter & moved \\
\hline 9 & female 56 & Renter & moved \\
\hline 10 & male 56, female 49, male 32 & owner & still lived in the segregated neighbourhood \\
\hline 11 & female 69, male died at the age of 66 & squatter & still lived in the segregated neighbourhood \\
\hline 12 & male - died at the age of 51 & squatter & still lived in the segregated neighbourhood \\
\hline 13 & male 51 & Renter & still lived in the segregated neighbourhood \\
\hline 14 & female 29 & squatter & still lived in the segregated neighbourhood \\
\hline 15 & male 41, female 47 & still lived in the segregated neighbourhood \\
\hline
\end{tabular}

ic - non-academic relations means that academics and scholars can get involved in numerous actions alongside non-academic partners. This allows the conventional "researcher versus subjects" roles to be replaced by a collaborative perspective, encouraging all voices to be expressed and to address 'undiscussables' (Bradbury \& Reason, 2003, p. 165). This is of utmost importance particularly in situations where researchers work with (and aim to produce valid knowledge about) stigmatised and segregated peoples, "closed" communities often being distrustful towards outsider researchers and research in general. It is therefore no surprise that structured qualitative inquiry, combined with cooperation and activism (although not necessarily within the framework of PAR), are popular approaches in empirical research on stigmatised, segregated Roma communities because they can ensure the validity of findings by supporting deep observations (see Clough Marinaro, 2017; Grill, 2018; Lancione, 2017).

The context of interviewing heavily defined the focus of interviews. Interviews were carried out with both present and former inhabitants of a segregated Roma neighbourhood in Szeged, Cserepes sor, which used to house approximately 240 inhabitants until 2017, when its elimination begun. 7 out of 24 houses have been destroyed until the present time.

During the interview process, four inhabitant groups were identified based on their housing situation: (1) apartment owners; (2) tenants renting apartments from the local public property company; (3) families legally residing in their apartment despite loss of legal status due to unpaid rent/overheads; and (4) illegal squatters without legal status who remain in their apartments, and illegal squatters in empty apartments.

We employed a qualitative content analysis (see Titscher et al., 2000) in order to create an open data analysis process, in which the study defines "stigma" in an open way, according to which perceptions of stigma and related social processes are left open to the perception of segregated Roma community members. In vivo codes were created during the first stage of the analysis. Then the codes were organised into different categories and their relationship was analysed. All interviews were analysed by two researchers and the results were compared and discussed until agreement was reached.

\section{Results}

\section{Dimensions of 'outside' / non-Roma stigma}

In general, Roma people are stigmatised by Hungarians. Several participants (e.g. Pál, male 51; István, male 60) emphasised that there is a huge difference between pre- and post-1989 political periods. Before 1989, Roma individuals had work and steady incomes and they were therefore not in such precarious financial positions, were better integrated and had more personal connections with Hungarians. After 1989, the employment opportunities for Roma have drastically dropped, leading to consistent lack of income, poverty, and social aid. Such processes have increased the separation 
of Roma communities from other groups and have negatively impacted their social relations with native Hungarians, leading to increased stigma and prejudice narratives. The vilification of Roma communities in Hungary is present even in highly educated individuals, with one participant arguing that:

There was no such friction [before]. There used to be togetherness between Roma and Hungarians. We do not have it anymore. Hungarians, high school students, university students, they are all very racist (Ilona, 56 years old Roma woman).

Such statements are in line with Foszto's (1918), and Crețan \& O'Brien (2019)'s ideas, addressing the fact that during socialism, the Roma people were also stigmatised and communities encountered hardships, but post-socialist neoliberal period has brought further major issues of job insecurity and unsafe housing. Therefore, post-socialism has been a gate for reinforcing racism, especially by intellectuals and politicians. Moreover, even in multicultural urban societies of Central and Eastern Europe, planning and policy documents do not account for the Roma people (Vesalon \& Crețan, 2019), which highlights policy neglect for the Roma people wellbeing in cities of this European region.

Occurrences of othering Roma can stem from the use of specific language and names, with one prominent example vilification of the name Kolompár, a typical name for Roma in Hungary: You should try to live with the name Kolompár for one year!"(Kriszti, Roma female, 29 years old). Another interviewee state that

If they [the Hungarians] hear "Kolompár", it makes their hair skin crawl. 80\% of non-Roma feels like that (Pál, 51 years old Roma man).

As a consequence of the negative association with the name, some Roma often even consider changing their 'Kolompar' names.

Despite surnames being easily changed, Hungarian accent provide another stigmatisation opportunity for those othering Roma. Most Hungarian Roma that we engaged with in our PAR activities speak Hungarian with a specific accent, making them recognisable as Roma and allowing those they communicate with to form opinions based on the way they speak. Our personal experience highlights this during a collaboration with a Roma lady looking for work (cleaning). The woman called a phone number provided in a job advertisement to apply, but was rejected immediately under the argument that "the position had been filled", despite one of the authors also calling the number 5 minutes after from a different phone num- ber, only for the person on the other line to attempt to persuade her for 5 minutes to take the job.

In this context, Roma family and personal names as well as their Hungarian accent is shown as a major problem that segregated Roma could encounter. Racism is reinforced on these patterns of Roma - non-Roma encounters in Hungary. The stereotyping of Roma communities is often also linked to their appearance. Hungarians seem to justify such attitudes by considering that there is a lack of sanitary infrastructure for the Roma communities, impeding their ability to have a bath every day, which reinforces their categorisation as others.

Besides stigma and prejudice associated with certain names, accents and physical appearance, illegal activities - such as stealing, are also often associated with members of the Roma community, as emphasised by a shop assistant who asked if school could teach [them] to stop stealing. This question was posed in light of the fact that only one of the several hundreds of Roma costumers, a mentally disabled teenager has ever been involved in an action of thievery in the shop. The vicious circle of poverty and stigma is further heightened by the lack of adequate education, employment opportunities and the often precarious housing situation of Roma communities (see Figure 2 and Figure 3), factors which reinforce stigmatisation, discrimination and marginalisation.

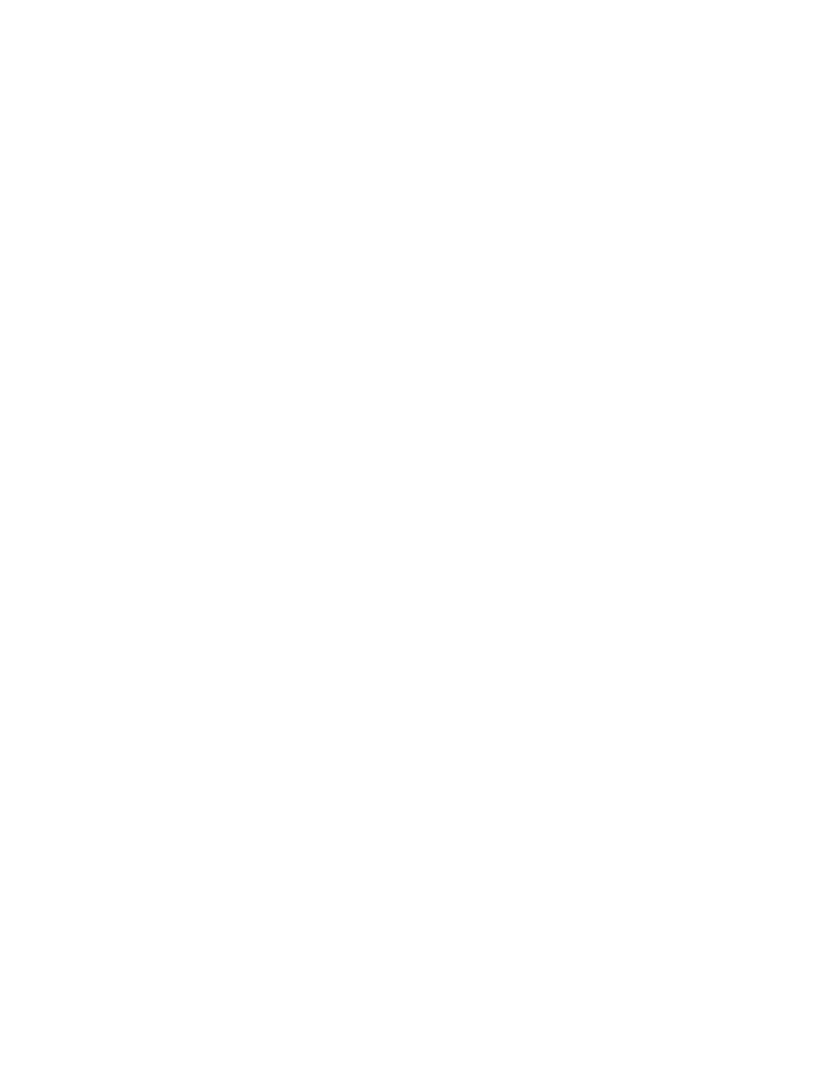

Figure 2. Roma housing conditions in Szeged Source: Méreiné Berki's photo collection 


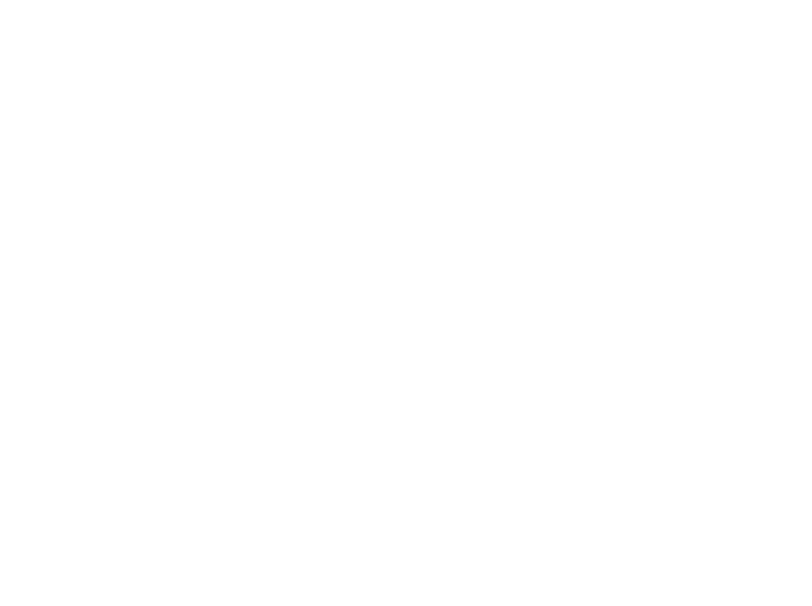

Figure 3. Demolished Roma house in Szeged Source: Méreiné Berki's photo collection

In East-Central Europe there is a huge debate about the Roma considered as 'outsiders' due to stealing and begging (Crețan \& O’Brien, 2019) and being highly considered as marginal people even during the current COVID-19 pandemic period (Crețan \& Light, 2020). Such stereotypes come from populism and different forms of superiority that some of the white majority reinforce in the public sphere.

Housing is another factor that impacts the level of stigmatisation and discrimination of Roma communities. Lousing and housing poverty (e.g. housing without basic labels of comfort paired with spatial segregation) makes Roma people prone to further vilification, which can explain why "lousy gypsy" remains a stereotypical insult in Hungarian language. Louse stigma leads to ostracism in kindergarten and school, with such cases highlighted addressed further in the discussion section. Furthermore, there is an apparent lack of rights and access to public services for the Roma in Szeged. For example, illegal squatters have no access to numerous public services and support like free food in school for kids and housing subsidies (Research diary). Such degrading attitudes against the Roma have been largely documented in post-socialist Europe, leading to extremist attitudes as Romaphobia (McGarry, 2018; van Baar, 2011).

\section{Dimensions of intra-Roma stigma: \\ stigmatising each other within \\ the disadvantaged neighbourhood}

In the Cserepes sor segregated area there is an interesting pattern of Roma stigmatising other Roma. Those Roma who are in a better socioeconomic position and are fortunate to have better jobs and own flats/legal rents within the segregated area stigmatise those who find themselves in more precarious circumstances (most of all those "from the Reptér", "illegal squatters", or "drugged Roma”), as emphasised by some of the participants in this research who detail the effect of the demolishing of one of the segregated area and the changes the space has suffered as a consequence:

I was born there [in the segregated area] and it did not use to be like this. There were more Hungarians than Roma living there. In 2000s the Reptér was demolished, and those gypsies came to Cserepes sor and this avalanche started: drugs, prostitution.... (Tamás, Roma man, 40 years old).

In addition to illegal squatting and activities linked with prostitution, the use of drugs is an extreme problem in present context, emphasising a major pattern of territorial stigma amongst the Roma from those in better socio-economic positions. Some of the interviewed participants discuss the negative impact of squatters on the general perceptions of the area, emphasising that illegal tenants are visibly more disadvantaged, leading to avoidance, discrimination, and marginalisation. One participant highlights the otherness within the community by arguing that

The normal ones have already moved out, those who had private property. They were the ones who were in a better position regarding their understanding. Those having legal rents, they also moved, and those who are still there, the illegal ones, the drug addicts, they are really the trash (Brigi, Roma woman, 29 years old).

Many of these segregated and stigmatised families "are so used to this milieu (of the segregated area) that it is impossible for them to integrate in the society" (Ákos, Roma male, 32 years old) - meaning that the segregated area is not part of "the society", but rather a place of otherness, with the society surrounding the segregated space. This issue has been discussed with a number of participants, some arguing that "many families that are illegal squatters could not fit in elsewhere. They act in a barbarian way, with each other, with others around them." (Edit, Roma female, 48 years old). Another participant addressed issues of appearance in the same context, emphasising the disapproval of squatting Roma towards her wanting to "be clean", her dress code, attitude, and general appearance, in comparison to Hungarians who appear to appreciate that. These perceptions of otherness, despite belonging to the same community, are detailed by the same participant in relation to the cleanliness of the living space, arguing that

When I told the Roma at Cserepes sor to join together and collect the garbage, they said I behave as a 
Hungarian. I want to be clean (Brigi, Roma female, 29 years old).

Personal relations can generate exceptions to the majority attitudes and behaviours (see Wacquant, 2008). The interviews uncovered one family that is frequently mentioned as such an exception, described as people "who would deserve not to be put on the street but to be given at least a small hole to stay", whilst "others, who previously had legal houses but left or sold them", should "get out of here, because they do not deserve [them]" (Edit, Roma female, 48 years old). Within this context, participants argue that, amongst the segregated community, there are those who "deserve" support and fair treatment, and those who "do not deserve" it, emphasising the intra-community stigmatisation discussed before:

You have to help those who want change. If you go to someone's place, you see whether she wants to change the whole thing. In case there is order, in case there is cleanliness, you can see the want for change. Otherwise not (Ilona, Roma woman, 56 years old).

Such attitudes and the increase of intra-community tensions are also the result of a previous displacement activity of the municipality concerning the Reptér segregated area - people from there moved in Cserepes sor area, became illegal squatters and "could not fit in", but changed the spaces in a way in which "everyone, who lived here for 25-30 years, said that we have to leave, it is unbearable" ( Pál, Roma male, 51 years old), creating "an environment where it is impossible to raise children normally because of these (drug addicts and their behaviours)" (Kriszti, Roma female, 29 years old). People associate better behaviours with individuals and kids who managed to move out of the segregated area, with some participants arguing that, as a result of the move, these people have become more calm, relaxed and "normal", highlighting the benefit of integrating into the majority society and living amongst Hungarians (Kriszti, Roma female, 29 years old; János, Roma male, 57; Edit, Roma female, 48; Tamás, Roma male, 40; Brigi, Roma female, 29). The prospect of being able to leave the segregated area offers hope of a future that is not achievable otherwise.

Stigmatising the area itself by former or present residents is also visible in different narratives, with interviewees arguing that

When we got there (in the segregated area) everyone thought we were Hungarians. They came to us to see who we were. They stole and took everything they reached. We were just watching [...] something al- ways disappears - cigarettes, remote controller. You get used to it (Lajos, 68 years old Roma man).

One of the participants who managed to leave the segregated area admitted to not missing anything about the space, being more relaxed, open, and happy (Brigi, Roma female, 29 years old). The same participants declared to now feeling like outsiders when looking at Cserepes sor, wondering how they had the strength and ability to survive in the segregated neighbourhood for as long as they did.

The stories that are presented above are part of an interesting form of 'in-group' territorial stigmatisation. Stigmatising their own territory refers to how the general society has influenced Roma's attitudes against the places they live in, and how Roma internalise such forms of vilification. Therefore, squatters are seen by most of the segregated Roma as 'the enemy other', the ones who are not part of their ethnic group. Such forms of vilification have increased mainly after the desegregation process appeared with increased stigmatisation emerging as a desegregation process result.

\section{Roma stigmatising other Roma -}

\section{generally not related to the given area}

Throughout the research, several interviewees consider that stigmatising other Roma in Hungary is a norm amongst most of the community due to a consistent lack of unity and group cohesion. One of the participants argued that "it is ok that I am a gypsy, I was born to be a gypsy, I am proud of it, just as my family, but I will not be trash. I can show that I make out from the other gypsies." (Tamás, Roma man, 40 years old), whilst another Roma justifies the intra-community stigmatisation by arguing that "gypsies are very greedy" and "would be glad if [my] children would marry Hungarians, and not Roma, because Hungarians are not as rubbishy as Roma." (Edit, Roma female, 48 years old).

General stigma towards Roma is apparent and sometimes even parallel, with one participant mentioning that they are facing "prejudices both because we are Roma and also because of Cserepes sor. Cserepes sor is infamous even in Budapest or Dunaújváros" (Tamás, Roma man, 40 years old).

Furthermore, another participant admitted to not wanting to live amongst Roma and preferring to live amongst Hungarians, because "Roma blood is awfully bad. Everyone is so unimaginative... Roma are worse than Hungarians." (Endre, Roma man, 51 years old).

\section{Emotional responses}

\section{of local Roma residents to stigma}

Emotional geographies on the Roma people are obvious in several of the most recent Roma studies, main- 
ly in those studies centred on the Roma narratives (see Grill, 2018; Crețan et al., 2021). Roma people usually reveal different forms of internalised stigma and responses to stigma (Crețan \& O'Brien, 2019; Crețan et al., 2021). The present study identifies several different responses of local Roma to stigmatisation: subordination; (de)humanisation; leaving the (segregated) area due to stigma, lack of trust and anger against other ethnic groups who stigmatise the Roma; cohesiveness and feeling safe together; and being and looking like Hungarians.

Subordination and internalising the stigma seems to be the preferred regular coping mechanism, with one participant arguing that some of the individual's talents, strengths and attributes that help them have a decent life within the segregated area would be worth very little outside the community, forcing them to bow down to the superiority of Hungarians (János, Roma man, 57 years old), whilst another participant believes that

Hungarians judge us for good reasons. We are bad in their eyes. We do not want to work. Indeed, we avoid what is demanding. Learning is very demanding, because we are dumb - globally, I believe. We are still littering, still use drugs, we could not show anything [of worth] in the past 5-10-15-20 years (Endre, 51 years old Roma man).

(De)humanisation has also been uncovered as an important issue that segregated Roma communities deal with. Numerous Roma participants talked about "nice Hungarians" that they know personally, including the owner of the flat they used to rent (Research dia$r y$ ), shop assistants in shops that they regularly visit or school directors at schools their children used to attend before they moved out of the segregated area, highlighting that personal relations can work against stigma:

First, when I went there, they came after me to see if I steal or not, and now they are interested in me as a person (Brigi, 29 years old Roma woman).

Another instance of personal relationships is further highlighted by another participant who describes his Hungarian neighbour as kind and helpful but emphasises that this relationship is the result of a successful, well-paid employment opportunity offered by the neighbour (Edit, Roma female, 48 years old).

Leaving the (segregated) area appears to be the only opportunity for change and a better life, as highlighted in previous sections as well. Furthermore, one participant's response emphasises that

The environment of the [segregated] area pulls you down. It is not good if there are many Roma in the same place, they are also envious if someone has more, steal and ostracise (Tamás, 40 years old Roma man).

Lack of trust and anger. Lack of trust in other ethnic groups and individuals that do not belong to the Roma community is sometimes a result of Roma stigma, with one participant arguing that, despite working and being in close contact with Hungarians, one can never know what their true intentions, beliefs and attitudes are (Anna, Roma female, 47 years old). Anger has also been identified as a possible coping mechanism against stigma and discrimination. One of the participants argued that Roma communities suffer from stigmatisation, stereotyping, and discrimination, despite often having similar behaviours to other people, particularly in relation to unemployment:

We were once at the changing room at work and one of my colleagues said: "those gypsies...". Well, I am a gypsy, why do you have to judge all of us? Why do you have to say "gypsies"? ... I feel hate, and the problem is that not only towards that given person who says it, but towards all Hungarians. [...] but after a while I forgive and then I can concentrate on the given person who talks like that (Ilona, 56 years old Roma woman).

Being (looking, living, and behaving) like Hungarians is another aspect that appears to be desired by some of the participants who admit that it would help them integrate. Despite their traditional views, some interviewees would like their children to marry Hungarians rather than other Roma:

This would provide my children with the opportunity to live normally. I do not want my children and grandchildren to go through the same racism I had to go through. [...] (Tamás, 40 years old Roma man).

Cohesiveness and feeling safe together have also been identified as defence methods against the repressive behaviour of the majority towards the Roma community. Feelings of safety stem from the unity of the group, as exemplified by one of the participants who describes an incident during which one of the community members was attacked and all other members rallied up in her support:

If someone is in trouble, the whole team goes to fight for him/her. This gives a sense of security for people (Brigi, 29 years old Roma woman).

Furthermore, the fear of not being able to integrate in other communities, paired with feelings of otherness increase the cohesion of the group, as reflected by another interviewee: 
It is also characteristic that if someone is self-confident in this place and milieu, because he is respected here, he loses it if he has to step out. Elsewhere he feels he is looked down on. He loses that self-confidence. [...] (Tamás, 40 years old Roma man).

Participants also highlighted that the primary positive aspect about living in the segregated area is the one for all, all for one attitude that is characteristic of close, segregated communities and generates feelings of safety, respect, and community spirit.

The above elements are clear-cut forms of perceived stigma by the segregated Roma in Szeged, which range from subordination to de-humanization. Different elements of feeling safe together and personal relations have been presented in the current literature as major lines of keeping the family united in urban outcasts (Wacquant, 2008). Such elements of family cohesion as a response to stigma have been met in certain instances in East-Central urban areas (Crețan \& O'Brien, 2019; Crețan et al., 2021). All these elements are completed by feelings of anger and lack of trust towards 'the others' but, at the same time, make most Roma wonder whether it would be better to be integrated and look, live and behave like Hungarians.

\section{Territorial and institutional stigma}

The negative impact of stigma in public spaces and institutions has been highlighted throughout this research, with numerous participants emphasising instances of discrimination in shops and other public spheres. Intra-community stigmatisation is also apparent and strongly justified throughout the responses of some of the participants, with one interviewee arguing that:

Half of the gypsies are banned from the tobacco shop and Aldi. You know why? They stink, they are dirty and sleazy. They smell of alcohol and do not take care of themselves. Not even the basic hygiene (Brigi, 29 years old Roma woman).

Similar responses emphasise that banning certain members of the community can be justified through their own behaviour and appearance, disregarding the stigma attached to the entire community.

Instances of institutionalised racism and stigmatisation towards the residents of Cserepes sor are also apparent in the responses of the participants, with one participant in particular detailing such experiences in the context of police brutality:

The police came there (Cserepes sor) at least 20 to 30 times a day, and if they saw a gypsy, they sprayed him and beat him up with their truncheon, even if he did not do anything (wrong) (Tamás, 40 years old Roma man).

One of the authors of the present article was also stopped by police when leaving the segregated area. After delivering firewood to two of the resident families, police officers stopped and performed a random drug search. After further enquiries, the police officer admitted having stopped the author because of visiting the segregated area, and not for any other reasons. Issues regarding the way police officers deal with the community of the segregated neighbourhood were also addressed by several participants (Erzsi, Roma female, 69 years old; Edit, Roma female, 48 , and Miklós, Roma male, 56), who argue that instances of theft and illegalities within the segregated area are left to be dealt with by the community members themselves, despite police checks being performed quite often in the area (Miklós, Roma male, 56). Instances of intracommunity violence are also dismissed by police according to interviewees who state that

When policemen see gypsies fighting with each other, they do not intervene, they just watch. [...] as long as no one is bleeding, they do not intervene (Ilona, 56 years old Roma woman).

The support of public offices and the access to public services is also severely limited for the community, with participants discussing several instances of appealing to public services for social aid and being met with dismissive and condescending attitudes (Brigi, Roma female, 29 years old). One of the participants highlights the effect of stigma in relation to the collection of waste in the Cserepes sor area by describing the extent to which the area is ignored by public waste disposal services and the blame the community receives, despite having no control over who disposes of garbage in the area:

There is a waste disposal site at both sides of a house, within the Cserepes sor segregated area. They collected the garbage once, but generally do not care about it. It is not only gypsies who dump their garbage there. Hungarians come by car and quickly empty their garbage there during the night. But it does not matter who puts it there, people who live there are blamed for the garbage anyway (Miklós, 56 years old Roma man).

Throughout the research, many statements relating to the unfairness of public service charges were uncovered, with many providers charging high amounts of money for different public services at certain times for the inhabitants of the ghetto. Extremely high liv- 
ing costs could be related to the fact that many of the houses within the segregated area are handled administratively as block of flats by the municipality. Thus, legal owners/tenants are expected to pay for the consumption of water, electricity and common services of the inhabitants who do not financially contribute within the block (e.g. illegal squatters).

The access to educational services and kindergartens in the area is also limited. There is a single kindergarten appointed for both segregated areas (including Cserepes sor) that accepts gypsy kids, but others, which are considered to be better, do not. This is clearly a stigmatising policy that maintains the segregation of the community, not only addressed by Roma members, but also by the director of one of these kindergartens. Generally, access to education for the Roma in Europe is limited, with segregation in school as a major pattern (O’Nions, 2010). By taking an insight into the interactions between teachers, school mediators, and Roma adults, Cerasela Voiculescu (2019) argued that current neoliberal state education include an utopian character of social integration for the Roma. The author points to a need for a constructive dialogue between state education and idiosyncratic Roma forms of knowledge and culture. Such a dialogue could help the Roma people to embrace authentic forms of empowerment.

Instances of stigma and unfair treatment of community members have also been observed in the private sector of service providers, with one participant arguing that the entire segregated area has been placed on a blacklist:

I phoned each and every service providers but they told me that they were sorry, but the computer shows that the Cserepes sor is on the blacklist, and they cannot provide us with internet subscriptions (Tamás, 40 years old Roma man).

As Pinkster et al. (2020) argue, territorial stigma and internalisation of stigma work together, and it is difficult to make a delineation between the two, but the 'stickiness' to certain territories and categories of people could be visible. If Alistair Sisson (2020)'s idea of defining the territory in 'territorial stigma' is to be considered, things look more complicated because for the Roma squatters in Szeged, 'home' and 'territory' is where they previously lived, the segregated area, even if that territory is a 'blemish of place' for the other segregated Roma.

\section{Discussions}

Collective identity is an important cultural form of identity (Hunt \& Benford, 2004). The Roma people have struggled hard to preserve their traditional values even though are living in segregated areas or in the mainstream society. Some of Roma's norms and habits are perceived by members of some other collective groups as disrepute and therefore bringing ahead issues of (territorial) stigmatisation against the Roma community. For instance, segregated Roma people in Szeged have been fighting with stigmatisation for decades (Málovics et al., 2019a; Málovics et al., 2019b; Méreiné Berki et al., 2017; Méreiné Berki et al., 2021). Dimensions of stigma are diverse and internalised in different forms, leaving the Roma at the bottom of the Hungarian society.

Furthermore, offers from the municipality towards the owners in exchange for their flats is also lacking transparency and are often considered unfair by members of the community who argue that the same offer should be made to all those who are in the situation of being able to sell their properties. Within this context, it becomes crucial to highlight that such instances are not only anti-gypsyism but also processes of anti-poorness. In Szeged - and in most other parts of Hungarythere is basically no social housing system serving the poorest and most disadvantaged. Most poor Roma are forced to rely on public work and unregulated employment which results in them not being able to apply to social housing support, since the per/capita official income limit (120 Eur/capita) is too high for them.

Being able to apply for social housing is not only limited by employment history and income but also by other administrative factors, included but not limited to people having been legally evicted in the past five years because of back rents and living costs. Additionally, the school system does not compensate for poverty to a significant extent either. It also does not deal with counteracting the stigmatization of Roma students in school on an institutional level, an issue highlighted by the same participant.

Stigma is highly reproduced due to housing conditions. Houses without basic levels of comfort result in additional stressors for the inhabitants, with daily struggles for people trying to fulfil their basic needs. Furthermore, inappropriate housing conditions also impact the opportunities for social mobility, as presented by Lancione (2017), who unveiled the post-human entanglements that shape human actions. Many Roma participants in Szeged have daily struggles of living in improper residential conditions.

The segregated area is legally organised into units of block of flats - meaning that even if someone has a pri- 
vate flat/house or rent in the segregated area, it is legally part of a larger housing unit, where the primary owner (owning more than $50 \%$ of the flats/houses) is the IKV, a local public property company. This gives the company a lot of power over other owners according to Hungarian housing law, particularly in relation to living costs.

The story of anti-segregation and the calculated informality of the local council have deepened the existing stigma. For a decade (more specifically from 2007 to 2017), the public property company (IKV) provided unjust buying offers for the apartments of the segregated Roma, paired with little to no coverage of the cost of relocating. Extremely small apartments, without basic levels of comfort, were offered in exchange for their present homes in the segregated neighbourhoods. These offers only began to improve in 2017 when the local public property company started to offer acceptable prices and exchanged the apartments with reasonable alternatives. Finding legal rent is almost impossible in Szeged (or even in other cities of Hungary) if you are a member of the Roma community, an issue repeated extensively by a large number of the participants. During the present research, petitions against Roma buying properties in an integrated part of the city were rising. Furthermore, the representative of the Local Roma Minority Self-government (LRMSG) also addressed instances of local representatives being afraid of placing Roma families in their voting districts out of fear of losing votes and the respect of the electorate.

The lack of transparency in addressing the anti-segregation process is further highlighted by members of the community without legal housing, who admit to feeling cheated and defenceless due to the lack of formal communication and information relating to their future residential status. This process deepened the stigma between segregated Roma and illegal squatters.

Illegal squatters are viewed from lack of transparency to total negligence. They do not officially exist for the city council in the desegregation process, often facing displacement, forced eviction and complete uncertainty. In the case of illegal squatters, Cserepes sor is seen as a last resort, whilst the negligence of administrative and development policies only serves to increase the hardships of those most marginalised. Given the uncertainty of tomorrow, the only possible outcome for illegal squatters in the context of desegregation processes is for them to move to another empty flat within the same building, creating a cycle of displacement. The risk of homelessness increases drastically for illegal squatters, pushing them from one stigmatised life to yet another. Due to stigma, the only employment opportunity for Roma in general is either public work or hard physical labour characterised by exceedingly difficult circumstances and severe uncertainty (see Messing \& Bereményi, 2017).

Territorial stigmatisation is a particularly important concept for understanding how spatial, social, and symbolic processes are interconnected in producing urban inequality (Pinkster et al., 2020; Sisson, 2020; Wacquant et al., 2014). In Szeged (territorial) stigma appears rooted in the balance between institutions and street-level bureaucrats. Generally, it can be argued that even if institutions themselves are not stigmatising the disadvantaged Roma, they do not support the empowerment of Roma either.

Even though, as acknowledged throughout this paper, there are institutional forms of support (e.g. free food in primary school and kindergarten; social services of the family support offices) that relate to social aid for the economically disadvantaged, including the Roma community, institutions do not provide meaningful assistance for empowerment (and social mobility), and the inadequacy of their support is heightened by stigmatisation. Institutions and their actors try to deliver forms of 'territorial destigmatisation' (Horgan, 2018) but their practices lead in fact to reinforced (territorial) stigmatisation. The services delivered are inadequate for meaningful social change for the community, an opinion emphasised both by the participants as well as further field observations. Although there are few examples of positive experiences linked to public officers (as street-level bureaucrats) who provide support to the community by helping them fill in paper work and offer advice and information, experiences towards institutions themselves is about hostility, stigmatisation and neglect.

The stigmatisation of Roma communities and, in particular, of members of the community who live in the segregated area, becomes apparent at the level of political debates too. During the interviews of the present research, numerous instances of othering the community in political and public debates, justifying the stigma through true versus untrue Hungarians have been highlighted by participants The othering of Roma communities is reproduced in the use of language by politicians, with some Roma arguing that the use of the word "minority" itself creates differentiation and stigma. The political and public vilification of the community does not consider the fault of the government itself, apparent through the consistent neglection of marginalised, disadvantaged people.

The role of Local Roma Minority Self-government (LRMSG) is quite limited in defending stigma. The system of LRMSGs is an extremely contradictory one in Hungary. Minority self-governments, including local Roma minority self-governments, are institutions created by Hungarian law to enhance political representation and inclusion of the Roma minority. Local 
Roma representatives in Szeged are members of the LRMSG, officially representing the local Roma community. Most of them grew up in the segregated Roma neighbourhoods and now live as socially integrated Roma citizens, committed to supporting their still marginalised and segregated peers. However, LRMSG rather hinders Roma representation and inclusion instead of supporting it. Some of the system's flaws include the lack of resources appointed to local Roma minority self-governments, corruption, ethno-business, and manipulation by "big politics". It is wellknown that corruption among political elites in cities of Central and Eastern Europe is a malpractice which could lead to questioning the right to the city (Crețan \& O'Brien, 2020).

Even though the system lacks adequate resources, it is still the only official institution for representing the interests of the community and members have expectations of their representatives that cannot necessary be fulfilled. The expectations of the community are often beyond the capacities and resources of the representatives and the system. In this context, the institution becomes the apparent scapegoat, allowing big politics to blame the lack of support on the LRMSG instead of dealing with the issues and policies themselves. Despite the awareness of "big politics" towards such situations and issues, their aim is not to change them, an opinion that appears often in the discussions with our participants. Institutional limitations often fall back upon Roma representatives. There is a need for representatives who really represent the rights of Roma. Current representatives mostly represent themselves. However, some of the members of the community are aware and understand the limitations of the institution.

\section{Conclusions}

The aim of the present research was to understand the perpetuation and internalisation of stigmatisation in the segregated urban space of Szeged. Therefore, the different dimensions of stigma and the various ways in which Roma communities internalise and contest it, have also been accounted for. Based on insight into the experiences and narratives of Roma individuals in Szeged, the present research highlights the nature of stigmatisation of urban Roma as reproduced mainly by non-Roma individuals but also by Roma community members.

In the context of urban stigmatisation of Roma communities, the results of this paper emphasise that the stigma process is complex and deeply rooted: the Roma are perceived as 'Kolompar', lousy, stinky individuals, who would never be able to get out of their condition, attitudes which lead to strong feelings of stigma internalisation for the local Roma people. Furthermore, the process of stigma grows from internalisation of stigmatisation for the Roma people, to territorial and institutional forms of stigma. Stigmatisation is reproduced on three levels: by the non-Roma against the Roma; by the segregated Roma towards other Roma within the segregated area; and by the segregated Roma people against other (segregated) Roma people..

The study highlights the harshest effects of stigma, uncovering that these are often generated by non-Roma, challenging issues of subordination, dehumanisation, actions of making the segregated urban Roma leave the (segregated) area, feelings of lack of trust and anger towards the non-Roma, as well as a desire for being, living, and behaving more like Hungarians. Territorial and institutional stigma are also internal- ised as strong patterns of vilification. Cohesiveness through personal relations and feeling safe together remain the only tools for the Roma to defend themselves against stigma. Against the 'ineducability' perception highlighted frequently in the neoliberal society (Shmidt \& Jaworsky, 2020), the Roma people have a very profound way of thinking practically. Their narratives indicate they are sensible people who internalise differently the actions of perpetuation of stigma.

Among the current causes of reproduction of stigma, the results of the present study address housing policies in particular. The lack of communicative transparency concerning the demolition and displacement process serves as an additional stressor for a community already facing precarious circumstances, a major issue emphasised by a number of the participants who are left not knowing what will happen, and how their lives will change. Moreover, illegal Roma squatters have emerged as a result of desegregation processes and form a new form of citizen in Szeged. Individuals belonging to this group have no idea when they will have to leave the segregated area, and their liminal condition has created an emergence of a process of in-group stigmatisation: the Roma stigmatising and discriminating against the other Roma.

In the context of traditional values and cultural differences, numerous Roma believe that stigmatisation and the implicit segregation of Roma communities stems from the cultural differences between the community and the majority group. The behavioural differences of both cultures are described by some Roma, who discuss not wanting to move to a flat offered by the city council, as the move would mean sharing the backyard with a Hungarian family leading to instanc- 
es of inter-ethnic conflict, which could arise as a result of cultural differences. However, contrary to dominant perceptions of Roma as unwilling to integrate, many Roma are agents of integrative bonds and trustful interactions (see Crețan et al., 2021).

Aside from the deeply rooted historical background, contemporary efforts towards desegregation and integration of urban Roma will be difficult to implement, especially because stigmatisation remains in the collective mentality of the majority. The findings of this research highlight an excruciating need for new studies to be conducted in (urban and rural) marginal areas, where Roma communities live, in order to determine if different forms of development, maintaining and contestation of internalisation of stigma can be observed. The limitations of the present study raise issues concerning the perspectives of local stakeholders on how to eradicate racial stigma towards the Roma people. This indicates a need for longitudinal ethno- graphic studies about the opinions of stakeholders on how to deal with the pressure of stigma on those communities. Moreover, as desegregation is a recent process in Szeged's disadvantaged neighbourhoods, at the moment we cannot make assumptions that desegregation has deepened certain patterns of stigma against the Roma. Therefore, further studies should take into consideration a longer time perspective on the relationship between desegregation processes and racial stigmatisation towards the Roma community.

The cycle of poverty and stigmatisation are connected to the lack of adequate education, employment opportunities and the precarious housing situation of Roma communities. Such elements reinforce patterns of stigmatisation and marginalisation. In this respect, the existing urban policies regarding the Roma people need to be readdressed, with clear power given to the voices of the Roma, particularly from institutions which aim to protect them.

\section{Acknowledgements}

We would like to thank the numerous marginalised Roma families for their long-term participation in this research. Special thanks go to Gyula Nagy for helping us with providing suggestions on the map of this paper, and also to the two anonymous reviewers for their feedback on the previous version of the paper.

\section{References}

Bajmócy, Z., Gébert, J., \& Málovics, G. (Eds.) (2017). Helyi Gazdaságfejlesztés a Képességszemlélet Alapján [Local Economic Development based on a Capability Approach]. JATEPress, Szeged (in Hungarian)

Berescu, C. (2011). The rise of the new European Roma ghettos: a brief account of some empirical studies. Urban Research and Practice, 4(3), 344-352. DOI: 10.1080/17535069.2011.616750

Berescu, C. (2019). How many ghettos can we count? Identifying Roma neighbourhoods in Romanian municipalities. In E. Vincze, N. Petrovici, C., Raț, \& G. Picker (Eds.), Racialized Labour in Romania: Spaces of Marginality at the Periphery of Global Capitalism (pp. 179-205). London: Palgrave Macmillan

Bradbury, H., \& Reason P. (2003). Action research. An opportunuty for revitalizing research purpose and practices. Qualitative Social Work, 2(2), 155-75. DOI: $10.1177 / 1473325003002002003$

Butler, A, Schafran, A., \& Carpenter, G. (2018). What Does it Mean when People Call a Place a Shithole? Understanding a Discourse of Denigration in the United Kingdom and the Republic of Ireland.
Transactions of the Institute of British Geographers, 43(3), 496- 510. DOI: 10.1111/tran.12247

Clough Marinaro, I. (2017). The informal faces of the (neo-)ghetto: state confinement, formalization and multidimensional informalities in Italy's Roma camps. International Sociology, 32(4), 545-562. DOI: $10.1177 / 0268580917706629$

Crețan, R, \& O'Brien, T. (2019). 'Get out of Traian Square!' Roma stigmatisation as a mobilisation tool for the far right in Timișoara, Romania. International Journal of Urban and Regional Research, 43(5), 833-847. DOI: 10.1111/1468-2427.12775

Crețan, R., \& Light, D. (2020). COVID-19 in Romania: transnational labour, geopolitics, and the Roma 'outsiders'. Eurasian Geography and Economics, 61, 4-5, 559-572. DOI: 10.1080/15387216.2020.1780929

Crețan and O'Brien, T. (2020). Corruption and conflagration:(in)justice and protest in Bucharest after the Colectiv fire. Urban Geography, 41(3), 368388. DOI: 10.1080/02723638.2019.1664252

Crețan, R., Kupka, P., Powell, R, \& Walach, V. (2021). Everyday Roma Stigmatization: Racialized Urban Encounters, Collective Histories and Fragmented Habitus. International Journal of Urban and Regional Research (forthcoming) 
Filčák, R., \& Steger, T. (2014). Ghettos in Slovakia: the environmental exclusion of the Roma minority. Analyse and Kritik 36(2), 229-250. DOI: 10.1515/ auk-2014-0203

Foszto, L. (2018). Was there a ,Gypsy problem' in socialist Romania? From suppressing, nationalism' to recognition of a national minority. Studia BabesBolyai Sociologia, 63(2), 117-140

Goffman, E. (1963). Stigma: notes on the management of spoiled identity. Hoboken, NJ: Prentice Hall

Goldberg, D. T. (2009). The threat of race: reflections on racial neoliberalism. New York: John Wiley \& Sons

Grill, J. (2018). 'In England, they don't call you black!' Migrating racialisations and the production of Roma difference across Europe. Journal of Ethnic and Migration Studies, 44(7), 1136-1155. DOI: 10.1080/1369183X.2017.1329007

Horgan, M. (2018). Territorial stigmatization and territorial destigmatization: a cultural sociology of symbolic strategy in the gentrification of Parkdale (Toronto). International Journal of Urban and Regional Research, 42(3), 500-516. DOI: 10.1111/14682427.12645

Humphris, R. (2019). Home-land: Romanian Roma, domestic space and the state. Bristol: Bristol University Press

Hunt, S., \& Benford, R. (2004). Collective identity, solidarity, and commitment. In D. Snow, S. Soule, \& H. Kriesi (Eds.), The Blackwell companion to social movements (pp.433-457). Oxford: Blackwell Publishing

Ivasiuc, A. (2020). Race matters: The materiality of domopolitics in the peripheries of Rome. International Journal of Urban and Regional Research (in press) DOI: 10.1111/1468-2427.12891

Kaló, Z., Móró, L., Demetrovics, Z., \& Felvinczi, K. (2017). A Mixed-methods Analysis of Online NPS User Discussion in Hungary. Drugs: Education, Prevention and Policy, 24(4), 340-47. DOI: 10.1080/09687637.2017.1327571

Kaplan, D. H., \& Douzet, F. (2011). Research in ethnic segregation III: segregation outcomes. Urban Geography, 32(4), 589-605. DOI: 10.2747/02723638.32.4.589

Kornai, J. (1980). The dilemmas of a socialist country: the Hungarian experiment. Cambridge Journal of Economics, 4(2), 147-157. https://www.jstor.org/stable/23596423

Lancione, M. (2017). Revitalising the uncanny: challenging inertia in the struggle against forced evictions. Environment and Planning D: Society and Space, 35(6), 1012-1032. DOI: $10.1177 / 0263775817701731$
Lancione, M. (2019). Radical housing: on the politics of dwelling as difference. International Journal of Housing Policy, 20(2), 273-289. DOI: 10.1080/19491247.2019.1611121

Maestri, G. (2014). The economic crisis as opportunity: how austerity generates new strategies and solidarities for negotiating Roma access to housing in Rome. City, 18(6): 808-823. DOI: 10.1080/13604813.2014.962895

McGarry, A. (2017). Romaphobia: the last acceptable form of racism. London: Zed Books Ltd

McElroy, E. (2020). Digital nomads in siliconising Cluj: material and allegorical double dispossession. Urban Studies, 57(15), 3078-3094. DOI: 10.1177/0042098019847448

Málovics, G., Méreiné Berki, B., Pataki, G., Juhász, J., Pálné Mihók, B., Szentistványi, I., Nagy, M., \& Tóth, J. (2018). Confronting Espoused Theories with Theories-in-use: Challenges of Participatory Action Research (PAR) with Marginalized Communities in Contributing to Social Change and Theory Building. Action Research (in press). DOI: 10.1177/1476750318774389

Málovics, G., Crețan, R., Méreiné Berki B., \& Tóth, J. (2019a). Socio-environmental Justice, Participatory Development, and Empowerment of Segregated Urban Roma: lessons from Szeged, Hungary. Cities, 91, 137-145. DOI: 10.1016/j.cities.2018.11.013

Málovics, G., Crețan, R., Méreiné Berki, B., \& Toth, J. (2019b). Urban Roma, Segregation and Place Attachment in Szeged, Hungary. Area, 51(1): 72-83. DOI: $10.1111 /$ area. 12426

Méreiné Berki, B., Málovics, G., Toth, J., \& Crețan, R. (2017). The Role of Social Capital and Interpersonal Relations in the Alleviation of Extreme Poverty and Spatial Segregation of Romani People in Szeged. Journal of Urban and Regional Analysis, 9(1), 33-50. DOI: 10.37043/jura.2017.9.1.2

Méreiné Berki, B., Málovics, G., \& Crețan, R. (2021). "You Become One with the Place": Social Mixing, Social Capital, and the Lived Experience of Urban Desegregation in the Roma Community. Cities (forthcoming)

Messing, V., \& Bereményi, B.Á. (2017). Is ethnicity a meaningful category of employment policies for Roma? A comparative case study of Hungary and Spain. Ethnic and Racial Studies, 40(10), 1623-1642. DOI: $10.1080 / 01419870.2016 .1213402$

O'Nions, H. (2010). Different and unequal: the educational segregation of Roma pupils in Europe. Intercultural Education, 21(1), 1-13. DOI: 10.1080/14675980903491833

Pinkster, F.M., Ferier, M.S., \& Hoekstra, M.S. (2020). On the Stickiness of Territorial Stigma: Diverging Experiences in Amsterdam's most Notorious 
Neighbourhood. Antipode, 52(2), 522-541. DOI: 10.1111/anti.12608

Powell, R. (2008). Understanding the stigmatization of Gypsies: power and the dialectics of (dis)identification. Housing, Theory and Society, 25(2), 87-109. DOI: $10.1080 / 14036090701657462$

Powell, R., \& Lever, J. (2017). Europe's perennial 'outsiders': a processual approach to Roma stigmatization and ghettoization. Current Sociology, 65(5), 680-699. DOI: $10.1177 / 0011392115594213$

Powell, R., \& van Baar, H. (2019). The invisibilization of anti-Roma racisms. In H. van Baar, A. Ivasiuc, \& R. Kreide (Eds.) The Securitization of the Roma in Europe (pp. 91-113). London: Palgrave Macmillan

Pulay, G. (2018). Crises, securitization and the Europeanization of Roma representation. Intersections, 4(3), 180-194. DOI: 10.17356/ieejsp.v4i3.489

Sisson, A. (2020). Territory and territorial stigmatisation: on the production, consequences and contestation of spatial disrepute. Progress in Human Geography (in press). DOI: 10.1177/0309132520936760

Shmidt, V., \& Jaworsky, B. N. (2020). Historicizing Roma in Central Europe. Between critical whiteness and epistemic injustice. London: Routledge

Teodorescu, D. (2019). Racialised postsocialist governance in Romania's urban margins: housing and local policymaking in Ferentari, Bucharest. City, 23(6), 714-731 . DOI: $10.1080 / 13604813.2020 .1717208$

Titscher, S., Meyer, M., Wodak, R., \& Vetter, E. (2000). Methods of Text and Discourse Analysis. London : Sage Publications

Toma, S., \& Fosztó, L. (2018). Returnees and their neighbors: migration of the Romanian Roma, networks, social distance, and local development. Szociológiai Szemle, 28(4), 37-60

Tyler, I., \& Slater, T. (2018). Rethinking the sociology of stigma. The Sociological Review, 66(4), 721-743. DOI: $10.1177 / 0038026118777425$

van Baar, H. (2011). Europe' s Romaphobia: problematization, securitization, nomadization. Environ- ment and Planning D: Society and Space, 29(2), 203212. DOI: $10.1068 / \mathrm{d} 2902 \mathrm{ed} 1$

van Baar, H., Ivasiuc, A., \& Kreide, R. (Eds.) (2019). The Securitization of the Roma in Europe. London: Palgrave Macmillan

Vesalon, L., \& Crețan, R. (2019). "Little Vienna" or "European avant-garde city"? Branding narratives in a Romanian city. Journal of Urban and Regional Analysis, 11(1), 17-34. DOI: 10.37043/jura.2019.11.1.2

Vincze, E., \& Rat, C. (2013). Foreword for the special issue on spatialization and racialization of social exclusion: the social and cultural formation of 'Gypsy Ghettos' in Romania in a European context. Studia Universitatis Babes-Bolyai Sociologia, 58(2), 5-21

Vincze, E. (2019). Ghettoization: the production of marginal spaces of housing and the reproduction of racialized labour. In E. Vincze, N. Petrovici, C. Raț, \& G. Picker (Eds.), Racialized Labour in Romania: Spaces of Marginality at the Periphery of Global Capitalism (pp. 63-95). London: Palgrave Macmillan

Voiculescu, C. (2019). Neoliberal governance, education, and Roma in Romania. Sociological Research Online, 24(3), 314-331. DOI: 10.1177/1360780419835558

Vrăbiescu, I. (2017). Roma migrant children in Catalonia: between the politics of benevolence and the normalization of violence. Ethnic and Racial Studies, 40(10), 1663-1680. DOI: 10.1080/01419870.2016.1229491

Wacquant, L. (2008). Urban outcasts: a comparative sociology of advanced marginality. Cambridge, UK: Polity

Wacquant, L., Slater, T., \& Pereira, V. B. (2014). Territorial Stigmatisation in Action. Environment and Planning A, 46(6), 1270-1280. DOI: 10.1068/ a4606ge

Zamfirescu, I., \& Chelcea, L. (2020). Evictions as infrastructural events. Urban Geography (in press). DOI: $10.1080 / 02723638.2020 .1778281$ 